\title{
Tax Mediation - an Alternative to the Resolution of Disputes between Taxpayers and the Local Tax Administration
}

\author{
Dorina Sandu \\ Bucharest Academy of Economic Studies, Doctoral School of Management, 6 Piata Romana, Bucharest, \\ Romania \\ e-mail: dorianasandu@googlemail.com
}

DOI: 10.51865/EITC.2021.03.10

\begin{abstract}
Local taxes and fees are of interest to both the public authorities and the taxpayer. The level of local taxes and fees guides the way the local budget is prepared and outlines the main investment objectives at the community level. The taxpayer has become increasingly interested in what he pays in local taxes and fees because he has realized that this effort on his part must be reflected in the level of well-being of the community in which he lives. This study aims at an analysis of tax mediation in Romania, as a distinct, special, and voluntary procedure between the tax institution and the debtor taxpayer, without the presence of the mediator as a third person, neutral and independent, comparing the institution of tax mediator in Romania with other EU countries presentation of the stages of mediation and its advantages in favor of both parties. The reality proves that there are numerous situations when fiscal administrative acts issued by the local taxes and fees service are the object of appeals before the issuing public authorities and the administrative-fiscal contentious courts. It complicates the activity of both local public authorities and courts, adds time consumption and financial costs, and fiscal mediation proves to be an optimal solution.
\end{abstract}

Keywords: public authorities; local taxes and fees; mediation; management.

JEL Classification: H83; H71; H12; J52.

\section{Introduction}

The relationship between the local tax administration and the taxpayer citizens is a special one. Taxes and fees are felt as obligations under the rule of the word must, of dissatisfaction with their legitimacy. Everything is felt as unpleasant, unwanted, because certain amounts established on the basis of certain criteria are paid individually and the collective benefit is lost sight of.

There are many cases of non-compliance with taxes, non-payment of the tax obligations, situations in which the tax administration can no longer fulfill its public service mission and litigation is reached, disputes between taxpayers and local government or between taxpayers and civil servants, and the appeals to the courts are becoming more frequent, although deadlines can be extremely long, due to the overburdening of the judiciary, a system that is also under the sign of reform needs.

The present study analyzes the institution of the fiscal mediator in Romania by comparing it with the one present in other states of the European Union with a much greater experience and a 
different way of organization. Using the method of triangulating various sources, the legislation on tax mediation at the national and European level, scientific analyzes in the field, I aimed to identify the methods and practices in tax mediation to bring an improvement to the institution of the tax mediator in Romania, an institution that is still in the incipient phase and little exploited by local tax administrations.

Promoting tax administrative mediation compared to court settlement has several advantages in favor of the parties: first, the dialogue would lead to a much better relationship between the taxpayer and the tax administration, the conflict could be turned into a positive relationship, the doubts related to the tax base, the amount of the amounts, the related delay increases would be clarified following the discussions between the representative or representatives of the tax administration and taxpayers.

Speaking about the special aspect of the local tax administration-taxpayer relationship, the ambivalent function of the public institution must be taken into account: on the one hand it is a public service in the service of the citizen; on the other hand it exercises fiscal control of taxpayers and notifies tax obligations. It is a contradiction, if we approach it only from this point of view and if the fiscal citizenship and the satisfaction of some needs at the level of the local community are missing from this equation.

Issues such as beneficiary, user, partner, or client are increasingly used to build the relationship with taxpayers and yet the authoritarian character is maintained, there is a presence of dissatisfaction, mistrust and a more or less visible rejection.

There is some pressure on local tax authorities to increase budget revenues, it is a permanent process to which is added a continuous change in tax legislation, which affects the degree of tax compliance of the taxpayer, and the tax disputes have become a reality that affects in a negative way both the activity of public services in the field of local taxes and fees, as well as the activity and the attitude of individuals or legal entities.

The objectives of the local tax administration are not limited to the collection of local taxes and fees, or other specific amounts established by law or decisions of the local council, but also include supporting taxpayers to facilitate the payment of these amounts.

A citizen who respects the law and the norm of law is aware of the legitimacy of taxation, does not evade fulfilling tax obligations, respects due dates or makes payments within the legal term, communicates when changes occur on their own tax situations.

Taxpayers can ask the tax administration for explanations regarding taxation, proposed corrections, regulatory-based motivations, and personal case analysis.

Taxpayers do not always agree with the position of the tax administration, with the assessments on taxes, the amount of taxation, the related accessories and choose to address the courts.

On the other hand, the tax institution may encounter situations of declarations that do not correspond to reality, do not include all the elements necessary for fair taxation, tax declarations do not comply with the facts and law, do not comply with the provisions of tax and accounting legislation, bases are erroneous or there are differences in tax obligations.

\section{Literature Review}

The local tax administration has developed and continues to develop a public relations policy designed to establish and strengthen the collaboration with individual or legal taxpayers.

The legislator has allowed the tax administration a series of legal means through which fiscal facilities can be accessed or granted in support of taxpayers (especially during the state of emergency and alert!), as the payment rescheduling, the penalties cancellation or restructuring (reorganization), although there has been and continues to be pressure on local tax authorities to increase budget revenues. 
The excessive bureaucracy and the lack of adequate communication betwen the public administration and the citizen, the distorted interpretations or the understandings of the law, the dissatisfactions of taxpayers turn into administrative-fiscal disputes challenging tax decisions, payment amounts, penalties. In addition, it should be noted that Romania, unlike other Eastern European countries, has failed to manage public administration reform, obviously not even fiscal reform, and we have fallen far short of the goal of strengthening a public system based on trust and efficiency (C. Vâlsan et al. 2020), a system capable of providing goods and services proportional to the amounts collected from taxes and fees.

The requests that have not been answered in time or the incomplete answers, which do not clarify the situation or do not support the granting of tax facilities cause the taxpayer to address the court as the only option to resolve the situation. It is a personal problem, but with social effects, because such situations reduce public revenues, block the ability to collect taxes, also affect citizens who have complied fiscally, and the quality of services provided (H. Ur. Rashid, 2020)

Analyzing the figures provided by the Portal of courts, it is found that at the level of the court competent to resolve disputes in administrative and fiscal litigation, in 2019, the number of new cases is somewhere around an average of 1500 . To these are added the files that are already in progress, and compared to the previous year, there is a general upward trend, which strengthens the opinion that the courts in Romania are increasingly overworked. Carrying out an analysis of the object of the files pending before the administrative and fiscal contentious courts, it is found that it is not possible to delimit the number of files challenging fiscal administrative acts, as at some courts the competence in administrative and fiscal contentious is reunited with the one in civil matters, thus determining a much wider area of competence.

And yet, starting with 2019, the Romanian legislator regulates in the Fiscal Procedure Code, fiscal mediation, as a distinct, special, and voluntary procedure between the fiscal authority and the debtor taxpayer, without the presence of the mediator as it appears as an independent third party in Law no. 192 / 16.05.2006 regarding the mediation and organization of the mediator profession, with the subsequent modifications and completions (M.O. no. 44 / 22.05.2006).

\section{Analysis}

The present study considered an analysis of the institution of the fiscal mediator in Romania by comparing it with the one present in other European states with a vast experience in this field. Using the method of triangulating various sources such as official reports of national public institutions, their official websites, relevant legislation, scientific analysis in the field, the aim was to identify methods and practices in tax mediation that could improve the institution of the tax mediator in Romania, an institution still in its infancy.

While in Romania we have been talking relatively recently about fiscal mediation, more precisely with the Order of the President of the National Agency for Fiscal Administration no. 1757 / 28.06.2019 for the approval of the mediation procedure, as well as of the documents that the debtors present in order to support the economic and financial situation (O.J. no. 549 / 04.07.2019) in many countries of the European Union, but also in other states of the world, there is the institution of the tax mediator, the tax conciliator or the taxpayers' ombudsman.

In France, for example, the institution of the mediator is regulated by Decree no. 612/ 26.04.2002 establishing the mediator of the Ministry of Economy, Finance, and Industry. The French mediator, according to art. 1 of the Decree, has the competence to resolve individual complaints regarding the functioning of the services under the competence of the Ministry of Economy, Finance, and Industry in relation to citizens.

In Belgium, the establishment of the institution of the mediator is defined by the dispositions of the Law of 25 April 2007 laying down various provisions (IV) regarding the tax conciliation framework, the way the organization and operation of the tax conciliation service subordinated 
to the Federal Public Finance Service, beeing regulated by the Royal Decree implementing Chapter VII of Title VII of the Law of 25 April 2007 laying down various provisions (IV). According to art. 9, the conciliation request can be submitted by any interested person, both in writing and by fax, email or orally through the direct lines provided by the mediation service.

The institution of mediation has been introduced in the Polish Code of Administrative Procedure since 2017. This amendment to the Code of Administrative Procedure comes with news on mediation, compared to the legal provisions of other states, in the sense that it is specified in the proceedings before administrative contentious courts. The amendments also introduce the notion of tax contract in the tax procedure. The concept of mediation is understood in Polish law as an effective solution to the amicable settlement of disputes between citizens and public administration authorities before or during judicial proceedings.

The purpose of this institution is on the one hand to help citizens - taxpayers in the tense or authoritarian relationship with the tax administration, and on the other hand to support the administrative authorities in adapting their decisions to the current situation. There is a close link between taxpayers' attitudes towards tax compliance and the misperception of the tax system. J. Farrar et al. (2018) (apud. H.Ur. Rashid, 2020), mentioned that the positive perception of taxpayers on the correctness of taxation has the effect of better cooperation with tax authorities, and M. Basilgan and B. Christiansen (2014) associated tax compliance with the taxpayer's income, the current economic situation, the functioning of the market economy, with a series of political indicators such as satisfaction with democracy and trust in government or demographics such as age, education, etc.

Considering the Directive no. 2008/52 / EC of the European Parliament and of the Council, mediation can be a structured process, assisted by a mediator in which two or more parties to the dispute, on their own initiative or on the recommendation of the court, try to reach an agreement on the settlement of the dispute between them.

In Romania, according to Law no. 192/2006 on mediation and organization of the mediator profession, the mediation is defined (Chapter I art. 1 par. 1) as "a way of resolving conflicts amicably, with the help of a specialized third party as a mediator, under conditions of neutrality, impartiality, confidentiality and with the free consent of the authorities".

Given the presence of the mediator, as a third party and at the same time an essential element of mediation, it differs from the Romanian Fiscal Procedure Code by introducing the mediation procedure (art. 230 par. 1), procedure based on which, once the payment order is sent, the informations on the initiative for such a procedure is also provided to taxpayers.

Promoting tax administrative mediation compared to court settlement has a number of advantages in favor of the parties: first, dialogue would lead to a much better relationship between the taxpayer and the tax administration, and the conflict could be turned into a positive relationship. In addition, all the doubts related to the tax base, the obligation amount and the penalties in case of nonpayment would be clarified following the discussions between the representative or representatives of the tax administration and taxpayers. The result from a fiscal point of view is a much higher degree of collection of amounts due, as it would involve the process of facilitating payment, staggering obligations, and a better understanding of the real tax situation of the taxpayer.

It should be noted that mediation, as regulated by Law no. $192 / 16.05 .2006$, it is possible even after the initiation of a trial or, in other words, even if the trial is pending before the courts and this was not done before the filing of the summons.

There are certain aspects regulated by law regarding the organization of mediation as an activity of public interest, the presentation to the mediator of one of the parties, the invitation of the other to appear for information and acceptance within 15 days, clarifications regarding the refusal of the other party, the impossibility of presenting at the place of mediation, etc., the 
mediation contract and its clauses, the conclusion of the mediation procedure, the mediation report.

Unlike classic mediation, fiscal mediation is regulated in the enforcement procedure: the steps or the model of mediation previously analyzed are followed, but this time we are talking about a special, voluntary mediation between the debtor and the tax authority, without the presence of the mediator.

The new fiscal mediation procedure, regulated by the introduction of article 230 par. 1 in the Fiscal Procedure Code and the Order of the President of NAFA no. 1757 / 28.06.2019 implies the clarification of the situation of the debtor's obligations when he has no objections regarding their type and amount and the analysis of the financial situation together with the fiscal body in order to identify the best solutions regarding the settlement of obligations, the possibility to benefit from payment facilities provided by the legislation.

According to the NAFA Order, art. 1 para. 1, the mediation procedure applies to debtors who have been notified of the summons and the start of the enforcement procedure, and they, within 15 days from the communication, submit to the competent tax authorities a notification regarding the intention to mediate, notification for which the order provides a model in annex no. 2, allows taxpayers to request in addition to clarifying the situation of the obligations entered in the summons and analysis of the economic and financial situation and the possibility to provide relevant information to justify the state of difficulty, temporary lack of cash. The debtor can also argue the payment possibilities and the time period.

Article 1 par. 3 of the mentioned Order specifies the fact that "the fiscal obligations, the fines of any kind, as well as other individualized budgetary receivables in the summons for which the notification was submitted are subject to the mediation procedure between the fiscal authority and the debtor".

It is recommended that the tax mediation procedure be carried out on the basis of analytical file or the analytical statement of debts, payments, balances to which, obligatorily will be added the documents proving the existence of the amounts to be reimbursed for which claims were made during the settlement, the situation of submitting the fiscal declarations, the situation of the individualized budgetary obligations in executory titles issued by other public institutions and sent as the case may be to the fiscal authority for recovery and any other type of documents relevant for the debtor's fiscal situation.

If, within 15 days from the communication of the summons regarding the initiation of the enforcement procedure, the debtors submit a notification of the intention to mediate, this procedure is suspended, but during the mediation procedure a series of precautionary measures may be ordered, because there is the danger of the debtor to evade, to modify his patrimony by hiding or by other means.

The introduction of fiscal mediation through the express regulation of the Fiscal Procedure Code and the specifications of the NAFA order was received and viewed from both pros and cons positions. First, the debtor has the opportunity to decide whether to opt for enforcement, a lawsuit or mediation procedure. The fiscal body is obliged to submit to the mediation intention expressed by the debtor and to order the suspension of enforcement, moreover it will have to provide in the content of the payment order and the debtor's right to resort to the mediation procedure and to manifest this intention.

The pros and cons of mediation were mentioned based on the following aspects:

0 Both the Romanian Government and NAFA created through the mediation procedure the possibility of dialogue, communication and negotiation between tax authorities and taxpayers, individuals, and legal entities;

o The tax authority is obliged to make known the right to mediation and is also obliged to respect this right; 
o By the effect of the law, the forced execution is suspended; it is the most important legal effect of resorting to mediation.

Regarding the negative aspects, the specialists in the field mentioned:

0 The tax mediation procedure is incorrect from the point of view of the name, the term comes from the Latin medium with the meaning of middle, center, and the verb mediare (closer to the current name) means to divide in the center or to be in the middle. We call mediation a negotiation procedure between the taxpayer and the authorities.

o The absence of the mediator, the essential and independent third party, supports the previous idea;

o The current mediation procedure is in fact a negotiation procedure; it could be a mediation procedure provided that the tax authority and the taxpayer agree on the appeal to a mediator, as an independent person, and that his intervention would be necessary or useful.

It must be noted for the present study the comprehensive definition provided by A. Dragodan (2019) for tax mediation as a legal institution - a negotiation procedure or "an amicable way of out-of-court settlement of misunderstandings between taxpayers and tax authorities, that is, the voluntary settlement of the tax claim, within the fiscal enforcement".

It must also be apreciated the legislative approach in filling this gap in the Romanian tax administration and alignment with the standards of other European countries.

In addition to the mentioned advantages, compared to the appeals specific to the legal system, tax mediation is primarily an economic process for all parties involved: costs of notifications, judicial stamp, drafting of proceedings, lawyers' fees, interrogations, etc. in short, time and money savings, speed, elimination of delays and length of processes. It is not the court but the parties that set the deadline within which the mediation must take place, a period from a few weeks to a few days, and the mediation itself can take several hours or at most a few days for overly complex situations.

When the parties go to court to resolve the dispute, the case is put on the record and thus brought to the public's attention, which does not happen in the case of mediation, when everything is confidential and remains known only to the parties, both the object of mediation and what is talking about.

If certain issues cannot be repeated in court, this is possible in the case of tax mediation, ensuring, in addition to confidentiality and transparency, the responsibility of the parties involved. It is hard to believe that following a dispute resolved in court, the taxpayer-tax administration relationship will be one without tension.

Fiscal mediation allows the mitigation of the conflict and the maintenance of a link that supports the future fiscal compliance, a link without animosities and negative feelings.

This collaborative approach on the part of those involved will certainly have effects on the future attitude of the taxpayer. In addition to transparency, confidentiality and accessibility, tax mediation allows for the maintenance of a relationship of trust and support for the recovery of the tax situation.

I considered these clarifications necessary because dissatisfaction was expressed regarding the regulation by the legislator at the beginning of 2019. Mediation is seen as a simple dialogue with the tax authorities based on unpaid debts, does not promise anything related to the reduction of these amounts or any some influence on these amounts. It all comes down to payment terms, installments, enforcement, without influencing the amount of the claim.

From this point of view, it can be considered that the mediation procedure provided in the normative acts of other European states is much more complex and gives the taxpayer the confidence that a favorable solution will be reached for both parties. Both France, Belgium and Poland have defined the mediation procedure as important for the existence and for the presence of an independent third party in the process, with a role in facilitating dialogue between the 
parties, thus maintaining the guidelines of the mediation concept provided in Law no. 192 / 16.05.2006, but not taken over by the Romanian legislator regarding the manner of carrying out the fiscal mediation procedure.

In France it is talking about the mediator subordinated to the Ministry of Economy, Finance and Industry, an autonomous administrative service, with correspondents at the level of each ministry in the three areas of competence (economy, taxation, industry).

As shown by the annual reports conducted by Tandem Expertise and taken over in the Report of the Ombudsman of the French Ministries of Economy and Finance for 2018, in the period 20022018 there is an increase in the number of mediation requests, most being recorded in 2017, as it can be seen in Figure no. 1.

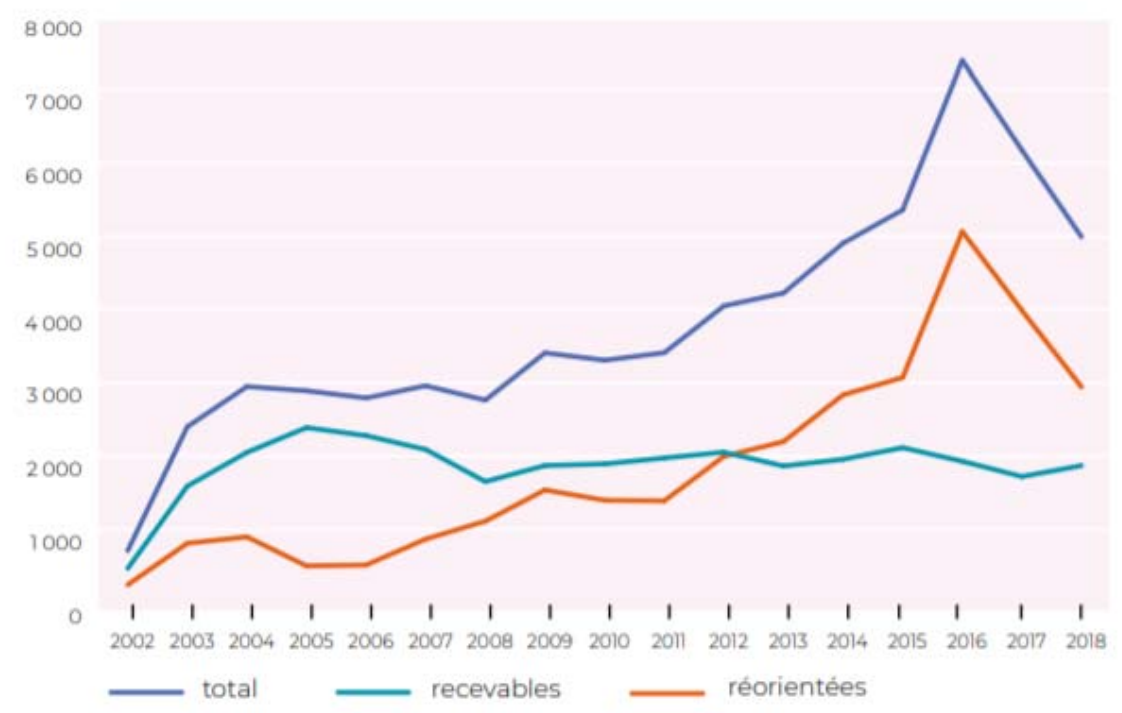

Fig. 1. The evolution of the mediation requests received by the French mediator $(2002-2018)$

Source: Annual and Tandem reports (from the 2018 Report of the Mediator of the Ministries of Economy and Finance).

The tax conciliation service subordinated to the Federal Public Finance Service has been set up in Belgium. Belgium has thus opted for the establishment of an authority with its own structure, consisting of at least 23 members elected for a period of 5 years with the possibility of renewing their mandate, coming from different national public institutions. They are independent during their term of office in the sense that they do not receive instructions from any other state authority. The service is run by a 5-member college, chaired by the Minister of Finance. Thus, it is a new authority with its own system of organization and internal regulation, with ways of resolving disputes depending on the category of fiscal obligations (affected by the state budget or local budgets). It can be considered that fiscal mediation in the Belgian system borrows defining elements of arbitration.

In Poland there is a list of mediators managed by the head of the National Revenue Administration, who are remunerated and entitled to the reimbursement of expenses incurred during the mediation procedure. It is perceived as a tool for mobilizing the tax authorities through which all the necessary efforts are made to solve a problem in agreement with the taxpayer, a solution that may or may not manifest itself by concluding a contract. Mediation is added to the list of tools for resolving conflict situations, along with conciliation, negotiation and arbitration.

In none of the cases specified above, the mediation procedure is carried out, as provided in the ANAF Order, by the presence only of the taxpayer and the tax authority in question. Fiscal 
mediation, as it is defined at the level of Romanian normative acts, can be described rather as a dialogue, and the solutions do not offer a middle ground, but rather seem to be a solution in favor of the fiscal authorities.

It must be admitted, however, that although this procedure does not meet the conditions of a mediation in the strict sense of the word, that following this process the amounts due may not decrease, the hybrid tax mediation provided by Romanian legislation has the advantage of reducing the possibility of abuses against the taxpayers, by initiating the forced execution without them having had the possibility to clarify the situation of fiscal obligations or to analyze their own economic situation.

With the exception of France, in the rest of the European countries in this comparative study there are no published reports on the number of mediations concluded because the mediation itself requires confidentiality. Poland has opted to publish the list of mediators and centralize activities without specifying the number. Returning to France, we note that since 2011 is published the Annual Report of the Fiscal Ombudsman with number of requests, key figures, database of mediators that can be requested, reform proposals. For the year 2020, for example, it is mentioned that almost 2000 mediations have been carried out, over $60 \%$ in favor of all or part of the interveners, 11 reform proposals have been made to avoid disputes between the administration and the natural or legal persons involved and a file on ongoing reflections in Parliament for future legislative proposals.

As specified in Annex no. 1 of the Order no. 1757/2019, art. 1 par. 5, the mediation procedure allows objections of the debtor regarding the obligations entered in the summons, in addition to the analysis of this situation, "in order to identify optimal solutions to settle obligations, including the possibility to benefit from payment facilities provided by law", situation in which the debtor is no longer enforced.

The regulation of the mediation procedure in the forced execution phase is another possibility granted to taxpayers for clarifying the economic situation and voluntary compliance with the payment of accumulated debts, along with the right to benefit from payment facilities, as they are defined and specified in Section 1 - Establishing the possibility of granting payment facilities, art. 184-209 of the Fiscal Procedure Code. It should be emphasized the restrictive nature of the possibility to use the mediation procedure, given that at the level of other states, this possibility is allowed at any stage of the tax procedure (Poland). The advantage of being able to resort to mediation at any time during the tax procedure is to increase the degree of trust, tax compliance and it can not rule out reducing the situations in which the tax authority uses the form of enforcement in order to recover tax claims. It is also noted that the Romanian legislator introduces the possibility of mediation at the request of the taxpayer, not being the intention of the tax authority to initiate such a procedure, as specified in the procedure established by the Polish system, for example.

The establishment of the possibility of granting payment facilities by the local fiscal body (art. 185) establishes the types of payment facilities - staggerings, postponements, exemptions or reductions of delay increases, the granting period, and the types of guarantees that taxpayers must provide.

In the case of the individuals (art. 185 par. 5 letter a), for the payment installments, the guarantee is "an amount equal to two average installment rates, representing staggered local tax obligations and calculated delay increases", and in case of deferrals, an amount resulting from the deferred debt ratio, delay increases and the number of months for which the deferral is granted. For legal entities, the guarantee must fully cover the staggered or deferred tax obligations.

The mediation procedure carried out at the level of the fiscal bodies, as specified in art. 3 of the Order no. 1757/2019 begins with the establishment of deadlines. No later than two days after 
receiving the notification of the intention to mediate, the tax authority has the obligation to notify the debtor when the meeting for mediation will be organized.

It should be noted that the date of the meeting should not exceed 10 days from the receipt of the notification of the intention to mediate. It is possible to communicate the notification online if the debtor can be contacted in this way.

The debtor's obligation is to appear at the date, time and place established in the Notice on the organization of mediation; he shall also be given the opportunity to arrange another meeting if the debtor, for good reasons, is unable to appear on time.

By mutual agreement, another time limit for the meeting may be set provided that the 10-day deadline for receipt of the notification of the intention to mediate is met, a situation considered delicate by some analysts because the enforcement measures are postponed even if the taxpayer does not appear. It is about the possibility to request another term for its organization, thus prolonging the suspension of execution. In the Belgian tax mediation procedure, the submission of a request for mediation results in the suspension of all acts and decisions taken in this regard. The period of suspension in the matter of recovery of tax claims is one month from the date of filing the application. The one-month deadline is a reasonable deadline given that the tax mediation is managed by an independent central authority that analyzes all requests from stakeholders throughout the state. But this term as well as the intention to reach an agreement of the taxpayer is not called into question, the hidden intentions in the sense of evading the fulfillment of tax obligations, because such behavior would have contracted the very idea of conciliation. Conciliation involves openness to negotiation and obtaining a favorable solution for both parties, not postponing / evading the fulfillment of certain obligations.

There is no article in the normative act that limits the possible number of mediations; it is only specified in art. 3 par. 13 that "in case the enforcement is not suspended, according to the law, and as a result of the organization of the mediation, the obligations entered in the summons are not extinguished or the payment is not requested, according to the law, the enforcement measures continue immediately the expiration of the term of 15 days from the date of drawing up the report on the result of the mediation".

Also, according to the law, within 15 days from the receipt of the summons, the debtor has the right to submit a notification regarding the mediation intention. Basically, it can once again suspend the enforcement through a new mediation notice. It is proposed that both the Fiscal Procedure Code and the NAFA Order no. 1757/2019 to amend and supplement certain provisions. The debtor should have the right to notify the tax authority once the intention to mediate. As mentioned in Order no. 1757/2019 (art. 3 par. 4), the fiscal authority ensures in order to achieve the fiscal mediation, the participation of two representatives from the departments / analytical evidence services and forced execution. If necessary, the hierarchically superior heads of the two services may also attend the mediation meeting.

The procedure, the result and the solutions adopted are signed in the minutes on the result of the mediation, in two copies, one for each party.

The minutes of the outcome of the mediation also raise issues of interpretation and application. In the standard report form attached to Order no. 1757/2019 specifies the continuation of enforcement, after drawing up the minutes, when the debtor does not appear at the date and time set for the organization of mediation as agreed in the notice on mediation or how the tax authority and the debtor agreed on the payments entered in the summons, payment facilities or suspension of enforcement when the debtor meets the conditions and participated in mediation.

However, it can be noted that the failure of the mediation followed by the non-execution of the established ones gives the fiscal authority the right to continue the enforcement procedure. The situation would have been much clearer and would not have given the possibility of 
interpretations if the specification had been inserted in the standard form that the report on the outcome of the mediation is enforceable.

It is also the reason why it was proposed that the fiscal mediation, present in many normative acts, should appear inserted in the Mediation Law no. 192/2006 as a section dedicated to the special provisions on conflicts of a fiscal nature, all the more so as it appears in the current documents, is left to the arbitrary discretion of the fiscal authority and does not provide conditions to be able to reduce the debt granted; it is negotiated, but no bilateral concessions specific to mediation are made as a legal notion.

If in the Belgian system the mediation is completed by a decision issued by the Tax Conciliation Service following the analysis of the documents provided by the parties and the analysis of their points of view, in the Polish system the mediation can be completed by a contract concluded between the parties, contract that involves the realization of concessions, in compliance with legal provisions, concessions likely to satisfy both parties, without excluding the possibility of cancellation / reduction of tax obligations.

The negotiation in the Romanian fiscal mediation, regarding the amount of the fiscal obligations, is limited to their staggering and not to the diminution, and then the question arises what is the point of staggering the mediation, considering the fact that this possibility was offered to the taxpayer before, it can stagger the tax obligations due without the need to resort to the mediation procedure, and the conditions for staggering the tax obligations are the same, regardless of whether it is requested as a result of concluding the mediation report or simply based on the procedure approved by Decision of Local Council.

In addition, besides the mediating conflicts between the tax administration and the taxpayer, the tax mediator, in the case of its regulation as an institution, could make proposals and recommendations to the Ministry of Finance on these issues.

In France, for example, in the event of a dispute with the tax administration - tax issues, tax calculation, etc. - it is recommended to support and appeal to the departmental tax conciliator or the mediator of the relevant ministry. Taxpayers have the possibility to resolve the admission or rejection of a complaint, a request for remission of penalties or the refusal of the payment deadline. The disputes over the quality of services may also be added. The tax conciliator can change the decision taken by the tax authorities / tax service and can ensure the speedy settlement of the dispute. The conciliator may not provide support for accounting audits or tax audits or disputes relating to land registration, retention of mortgages, etc. the taxpayer having the obligation of a preliminary approach to the fiscal service before the appeal to the departmental conciliator.

By registered letter, a request is addressed to the tax service, requesting the subject of the dispute. If the request does not receive a satisfactory response, the tax conciliator is contacted.

In other words, the mediation starts as the request at the initiative of the debtor and not of the fiscal body. In the event that neither the response of the tax service nor of the departmental conciliator is satisfactory, the taxpayer appeals to the mediator of the relevant ministry, mentioning all the relevant details and attaching to the request all important documents. The mediator can support the settlement of disputes related to the calculation or payment of tax, payment of fines, customs duties in the event of disputes with the customs administration.

Following the examination of the case, the mediator may make a recommendation to the service concerned. If the tax administration does not agree with this proposal or recommendation, the mediator submits the case to the minister who will decide on the solution to be given.

The mediator has the competence to rule on disputes between the taxpayer and any service assigned to the Ministry of Economy and Finance.

The fiscal mediation procedure proposed in our country is a simplified procedure. In the absence of the institution of the tax mediator / conciliator or ombudsman of the taxpayer, it is 
the responsibility of the tax administration to organize this procedure. Countries where these procedures are grounded have seen an increase in requests for mediation, and solutions have come to support tax administrations, not only by resolving disputes but also by improving the quality of tax services, identifying, and removing legislative and procedural gaps, by promoting dialogue open and fair between the taxpayer and the tax service.

The effort of the Romanian legislator in offering the possibility of fiscal mediation is to be appreciated, even in the forced execution phase. The presence of a third party is missing, which makes it more of a self-mediation of the conflict or a negotiation. It is understandable the position of lawyers or mediators regarding the proposals of the law ferenda, meaning the establishment of the institution of fiscal mediation followed by the need to create the position of mediator of the Ministry of Public Finance (Ministry of Development, Public Works, and Administration - under which local public authorities) and that of regional fiscal conciliator.

It is considered that regarding the institution of mediation, the presence of the tax mediator as a third party would not only resolve conflicts that can become costly financially and / or temporarily but would also solve the great problem of trust between taxpayer and tax administration, trust followed by a real mutual respect.

As I mentioned above, starting from the analysis of the French example, taxpayers are the ones who voluntarily choose whether or not to turn to a conciliator, tax mediator or court.

In the case of the Romanian legislator, it was offered the possibility to clarify the origin, the level of the amounts, of the increases for non-payment based on a direct and open discussion between the taxpayer and the representative of the fiscal body.

Obviously, many minor conflicts in the tax field are resolved, the judiciary is given the opportunity to deal with major disputes, the collection of tax claims is increased, and the person who initiates the mediation procedure from the tax institution and participates in this meeting has a good training in the field and knows very well the taxpayer's tax situation.

It must not be forgotten, however, that every taxpayer, an individual and legal person, has the right to pay only what he owes, has the right to confidentiality and to challenge the amounts imposed, to the official review of taxes and accurate and complete information in a timely manner. Under the tax legislation can be considered payment installments, exemption from increases. If a taxpayer cannot be present for the analysis of the tax situation in the case of tax mediation, as it is understood at the level of the tax institution, he can be represented by another person who knows very well his tax situation.

\section{Conclusions}

Carrying out as many such procedures as possible is an important tool in building relationships, encouraging tax cooperation and compliance, engaging in open dialogue, and convincing those concerned of fair treatment.

An individual or a legal person in a situation that requires tax mediation is affected both financially and emotionally. I suggest individual treatment for common situations, as the causes that made it impossible to pay can be better understood. Many of the barriers to the institutional mediation process would be removed and a people-to-people service would be demonstrated.

The situation would be understood differently, and the best solutions would actually be adopted. Always or most of the time the initiation and development of the mediation procedure creates confusion, frustration, the conviction on the part of the taxpayer that he will have a lack of understanding. The process itself should be conducted in such a way that the taxpayer finds himself in tax mediation as a beneficiary of a procedure.

A number of gaps can be identified in the activity of the tax administration, in communication with taxpayers. Driving change and dialogue would create better ground for promoting 
voluntary compliance, educating citizens about tax legitimacy, and streamlining the work of tax services.

The tax administration can improve the services it offers while assuming responsibilities for what it offers and how it treats the taxpayer.

The fiscal mediation must be perceived in Romania following the successful example of other European states: a manifestation of changing the vision regarding the functioning of central and local public authorities and an important step on the road to good governance.

A successful mediation, beyond what is included in the report on the result of successful mediation, means professionalism, efficiency, fairness and especially respect.

\section{References}

1. Bureau de l'ombudsman des contribuables, 2019. Rapport annuel 2018-2019. Éliminer les obstacles au service. Available through: https://www.canada.ca/fr/ombudsmancontribuables/programmes/rapports-publications/rapports-annuels/rapport-annuel-20182019.html\#toc0.

2. Code of Administrative Procedure of Poland, 1960. Code of Administrative Procedure with subsequent amendments and completions. Available through:http://isap.sejm.gov.pl/isap.nsf/download.xsp/WDU19600300168/U/D19600168Lj.pdf

3. Decree no. 2002-612 of April 26, 2002 establishing a mediator of the Ministry of Economy, Finance and Industry. Available through: https://www.legifrance.gouv.fr/loda/id/JORFTEXT000000407822/

4. Dragodan, A., 2019. Innovation of the enforcement procedure in fiscal matters by introducing in Romania the mediation between the debtor and the fiscal body. Proposed law ferenda: regulation in Romania of the institution of the fiscal mediator (mediator of the Ministry of Public Finance), Journal of Public Finance and Accounting no. 6/2019, pp. 37-54.

5. Dragodan, A., 2015. Institutional mediation and the fiscal mediator for the amicable settlement of disputes in fiscal matters and the increase of voluntary compliance - aspects of comparative law, Journal of Public Finance and Accounting no. 11-12 / 2015.

6. European Parliament and of the Council, 2008. Directive 2008/52 / EC of the European Parliament and of the Council of 21 May 2008 on certain aspects of mediation in civil and commercial matters, O.J.L. no. $136 / 24.5 .2008$.

7. Basilgan, M. and Christiansen, B. 2016. Taxpayers' Attitudes towards Tax Evasion in Latin American Countries. International Business: Concepts, Methodologies, Tools, and Applications, DOI: 10.4018/978-1-4666-9814-7.ch064.

8. NAFA (National Agency for Fiscal Administration), 2019. Order of the President of the National Agency for Fiscal Administration no. 1757/28.06.2019 for the approval of the Mediation Procedure, as well as of the documents that the debtors present in order to support the economic and financial situation, M.O. no. 549/04.07.2019.

9. Parliament of Romania, 2006. Law no. 192 / 16.05.2006 on mediation and organization of the mediator profession, with subsequent amendments and completions, M.O. no. 441/22.05.2006.

10. Parliament of Romania, 2019. Law no. 30/2019 for the approval of the Government Emergency Ordinance no. $25 / 2018$ on amending and supplementing some normative acts, as well as for the approval of some fiscal-budgetary measures, M.O. no. 44/17.01.2019.

11. Rashid, H., 2020. Taxpayer's Attitude Towards Tax Evasion in a Developing Country: Do the Demographic Characteristics Matter?, International Journal of Applied Behavioral Economics, DO10.4018/IJABE.202004010

12. Royal Decree implementing Chapter VII of Title VII of the Law of 25 April 2007 laying down various provisions in Belgium. Available through: https://www.etaamb.be/fr/arrete-royal-du-09-mai2007 n2007003250.html

13. Vâlsan, C., Druică, E. and Ianole-Călin, R., 2020. State Capacity and Tolerance towards Tax Evasion: First Evidence from Romania. Adm. Sci. 2020, 10,33. https://doi.org/10.3390/admsci10020033

14. ***, 2019. Amnesty, staggering and fiscal mediation 2019-2020, Con Fisc, Bucharest. 